Article

\title{
Study of the Effects of Land Use on Hydrochemistry and Soil Microbial Diversity
}

\author{
Hongying Zhang, Zongjun Gao *, Mengjie Shi, Shaoyan Fang, Hailong Xu, Yechen Cui \\ and Jiutan Liu
}

College of Earth Science and Engineering, Shandong University of Science and Technology, Qingdao 266590, China; zhy10sdust@126.com (H.Z.); smj_sdust@126.com (M.S.); fsysdust@126.com (S.F.); xhlsdust@126.com (H.X.); cycsdust@126.com (Y.C.); litsdust@126.com (J.L.)

* Correspondence: zongjungao1964@163.com; Tel.: +86-0532-80681106

Received: 16 January 2019; Accepted: 28 February 2019; Published: 5 March 2019

\begin{abstract}
The objectives of this study were to compare the influence of land use, to determine which land has an impact on hydrochemistry and to clarify the impact of land use on soil microbial diversity and the correlation between hydrochemistry and soil microbial diversity. The impacts were assessed through chemical and biological data from 4 land-use groups. The results showed that soil microbial diversity and water chemical composition were different under different land uses. There was a strong correlation between the main hydrochemical components under different land uses, and the M03 had the highest correlation. The Shannon index was the largest for M01, the Simpson index was the smallest for M01, and the Chao1 and Ace indexes were the largest for M02. Actinobacteria, Proteobacteria and Acidobacteria were the dominant bacteria with different land uses, and some bacteria were present or absent depending on the land use. It was found that the soil $\mathrm{CO}_{2}$ content was different with different land uses. Soil $\mathrm{CO}_{2}$ content, hydrochemistry and soil microbial species were related to each other. A heatmap analysis showed that the $\mathrm{F}^{-}$and soil $\mathrm{CO}_{2}$ content showed a strong correlation with soil microorganisms and that the dominant bacteria were positively correlated. Under different land uses, hydrochemistry, soil $\mathrm{CO}_{2}$ and soil microorganisms interact with one another.
\end{abstract}

Keywords: land use; hydrochemical; soil $\mathrm{CO}_{2}$; soil microbial

\section{Introduction}

In 1995, the International Geosphere-Biosphere Program and the Global Environmental Change Humanities Program jointly proposed the "Land Use and Cover Change (LUCC)" research program, making research on changes in land use the forefront of global change research. In recent years, the environmental effect of land-use change on different scales has gradually become a research hotspot, and the environmental effect of water is the focus of considerable attention [1,2]. Land use patterns have a very important influence on water quality and water ecosystems. Many water quality problems are caused by inappropriate land use, such as urbanization and agricultural activities [3]. Meanwhile, soil microorganisms can participate in the regulation of ecosystem processes at all scales and can provide power for the carbon and nitrogen cycles. Soil microbial diversity can be affected by many factors [4]. In recent years, scholars at home and abroad have conducted a large number of studies on the relationship between land use (landscape pattern) and water quality on different scales using different methods, and many excellent results have been revealed [5,6]. Bornstert et al. discovered that two modelling studies of mesoscale catchments in Germany were presented: the first showed the possible impacts of climate change on storm runoff production, and the second showed the impact of land-use changes [7]. Jiang et al. studied the effect of land-use changes on groundwater quality 
in the small watershed of Huxi County of Yunnan Province over the years and found that the total alkalinity and $\mathrm{pH}$ plasma content in groundwater increased [8]. Jia et al. studied changes in the two types of hydrochemical indexes of conventional hydration ions and heavy metal ions in shallow karst groundwater caused by land use and found that there was a high degree of dynamic consistency between the ion content and the change of land use [9]. Guo et al. found that the hydrochemical index for groundwater in areas with strong human activity was high, indicating that the land use had a significant impact on the quality of karst groundwater [10]. At the same time, other scholars found that an area's classification as a forest, grassland or arable land had a relatively significant impact on water quality [11]. The study found that the relationship between water quality and land use as well as the ability of land-use indicators to explain water quality vary across the urbanization gradient in the studied watersheds [12]. Duan et al. studied the impact of land use on water quality at different scales in the Sancha River Basin and found that forests and grasslands play the role of a "sink" for water quality [13]. Zhang $\mathrm{M}$ et al. found that $\mathrm{K}^{+}$and $\mathrm{SO}_{4}{ }^{2-}$ in shallow groundwater were positively correlated with agricultural land, while $\mathrm{Na}^{+}$was mainly correlated with urban land, and that $\mathrm{Cl}^{-}$was affected both in agricultural land and urban land [14]. The nitrate nitrogen $\left(\mathrm{NO}_{3}-\mathrm{N}\right)$ concentrations significantly increased by approximately $8.1 \%$ and $3.89 \%$ annually in agricultural and residential wells, respectively [15].

On the other hand, land use can change the soil nutrient cycle and soil microbial activity through water, heat and other environmental conditions and then can change the soil microbial community structure [16]. Mader et al. found that no-tillage or low-tillage agriculture could significantly increase the number and microbial activity of soil microorganisms in the surface layer $(0-10 \mathrm{~cm})$ through a 10-year localization experiment [17]. Sun et al. believed that a no-tillage agriculture increased the soil bacteria content and promoted the degradation of soil organic matter by fungal microorganisms but had no effect on soil Actinomycetes [18]. Poulsen et al. found that soil microbial diversity and richness are determined by soil type and particle composition rather than by fertilizer application [19]. Additionally, no significant alterations in the alpha diversity were observed among different land uses, but the beta diversity in grasslands was lower than that observed in forests and no-till soils [20]. Deng et al. found that the metabolic activity of the soil microbial community was significantly different under different land-use patterns and that the Shannon index of the soil microbial community in a maize farmland was lower than that in other land-use patterns [21]. Li et al. found that the effect of no-tillage agriculture on soil microorganisms was significantly less than that of green manure cultivation [22].

In early research, scholars only studied the impact of land use on water quality or microorganisms and rarely considered both. Through differences in land use, this paper studies the hydrochemical changes and the changes in microbial diversity, as well as the correlation between them, to provide new ideas for the study of soil microbiology and to highlight the direction for further research of the hydrochemical evolution process. The combination of soil microbiology and hydrogeology provides important significance for future research. The influence of the land-use mode on environmental water quality is not only a hot topic but also a difficult topic in current research [23] and has very important theoretical and practical significance. The main aims of this study were to compare the influence of land use, to determine which land has an impact on hydrochemistry and to clarify the impact of land-use on soil microbial diversity and the correlation between hydrochemistry and soil microbial diversity.

\section{Materials and Methods}

\subsection{Study Area}

The demonstration park is located in the Qi-Longwan village of Laiwu (Figure 1) at $36^{\circ} 22^{\prime} \mathrm{N}$ $117^{\circ} 38^{\prime}$ E. It belongs to a hilly area in the middle and south of Shandong Province, and it represents the main type of soil erosion in the northern mountainous area. The park is in a temperate humid 
and semi-humid continental monsoon climate. It is characterized by obvious seasonal differences: cold with little snow in winter, dry and windy in spring, hot and rainy in summer, and dry and cool in autumn. The annual average precipitation is $732 \mathrm{~mm}$, and most heavy rainfall occurs in summer. The average precipitation in summer (June-September) is $561.9 \mathrm{~mm}$, which accounts for $73.89 \%$ of the total annual precipitation. The maximum precipitation in one year was $1352.8 \mathrm{~mm}(1964)$, and the minimum precipitation in a one year was $370.8 \mathrm{~mm}$ (1989); the difference was $982 \mathrm{~mm}$. The National Water and Soil Conservation Science and Technology Demonstration Park in Laiwu was planned and constructed by Shandong Agricultural University, the Water Resources Research Institute of Shandong Province and the Soil and Water Conservation Office of Laiwu. The park is used to monitor the soil erosion intensity and hydrological characteristics of different vegetation and slopes. In 2007, the Ministry of Water Resources was listed as the typical small watershed monitoring point of the National Soil Erosion Dynamic Monitoring and Announcements Project (No. 0A37200133130). It was named the "Science Popularization Education Base in Shandong Province" by the Shandong Association for Science and Technology in 2011. In 2012, it was named the "National Water and Soil Conservation Science and Technology Demonstration Park" by the Ministry of Water Resources. The soil layer in the experimental plot is brown soil. The depth is approximately $70-80 \mathrm{~cm}$ with light brown sand, a slightly granular structure, and loose and porous soil. Plant roots are developed, and animal caverns exist. The bedrock is mainly granite and gneiss.

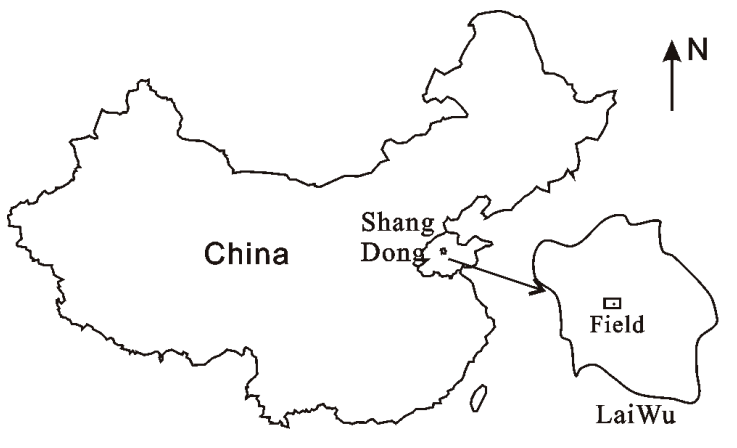

(a)

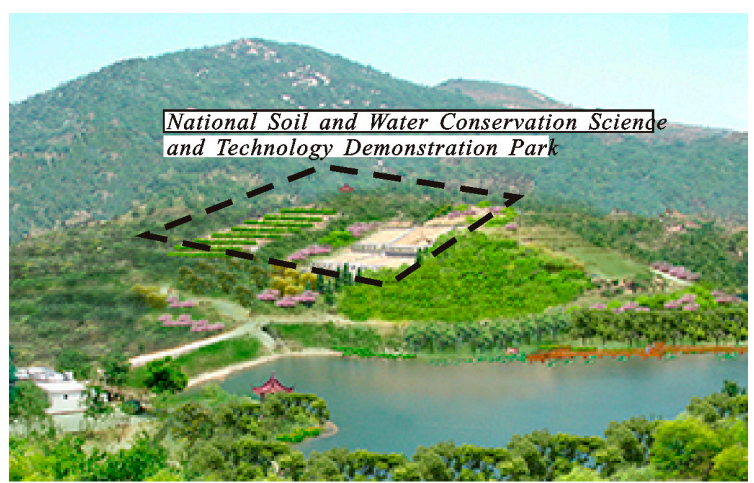

(b)

Figure 1. A diagram of the experimental plot location ((a) map of the traffic in the experimental plot; (b) photo of the experimental plot).

\subsection{Methods}

The experimental plot was designed to be $5 \mathrm{~m}$ wide, $10 \mathrm{~m}$ long and $50 \mathrm{~m}^{2}$ in horizontal projection area. The upper part and both sides of the prefabricated bracer arranged outside the protection zone had a width of $2 \mathrm{~m}$. Different vegetation was selected to be planted in the experimental plots (Figure 2). The specific land-use types are shown in Table 1. According to the 4 plots with different land-use modes (M01-M04), the center point was set as the experimental observation point. Soil and water samples were collected, and the sample numbers are shown in Table 1.

Table 1. The sample number and land-use type.

\begin{tabular}{ccccc}
\hline Sample & M01 & M02 & M03 & M04 \\
\hline Land-use type & Bare & Peach & Castanea & Pine \\
\hline
\end{tabular}

\subsubsection{Hydrochemical Detection}

After precipitation, the mixed water samples from a soil depth of $0-15 \mathrm{~cm}$ were collected and the hydrochemical indexes were tested. The water samples were collected in dry and clean polyethylene 
bottles. The $\mathrm{pH}$ value was measured at the site using portable measuring implements (HQ40d, $\mathrm{HACH}$, Danaher Grop, New York, NY, USA). All the samples were stored and transported at $4{ }^{\circ} \mathrm{C}$ to a laboratory for further analysis. The major cations in the water samples were analyzed in the laboratory. The total dissolved solids (TDS) was measured by evaporating a prefiltered sample to dryness. The major cations $\left(\mathrm{Ca}^{2+}, \mathrm{Mg}^{2+}, \mathrm{K}^{+}\right.$and $\left.\mathrm{Na}^{+}\right)$were measured by a flame atomic absorption spectrophotometer. $\mathrm{SiO}_{2}$ and major anion $\left(\mathrm{Cl}^{-}\right.$and $\left.\mathrm{SO}_{4}{ }^{2-}\right)$ concentrations were determined using ion chromatography. Free $\mathrm{CO}_{2}$ and $\mathrm{HCO}_{3}{ }^{-}$were sampled and titrated immediately on site to prevent atmospheric carbon dioxide pollution. The ion balance errors of the water samples were $<10 \%$, and most of them were $<5 \%$.

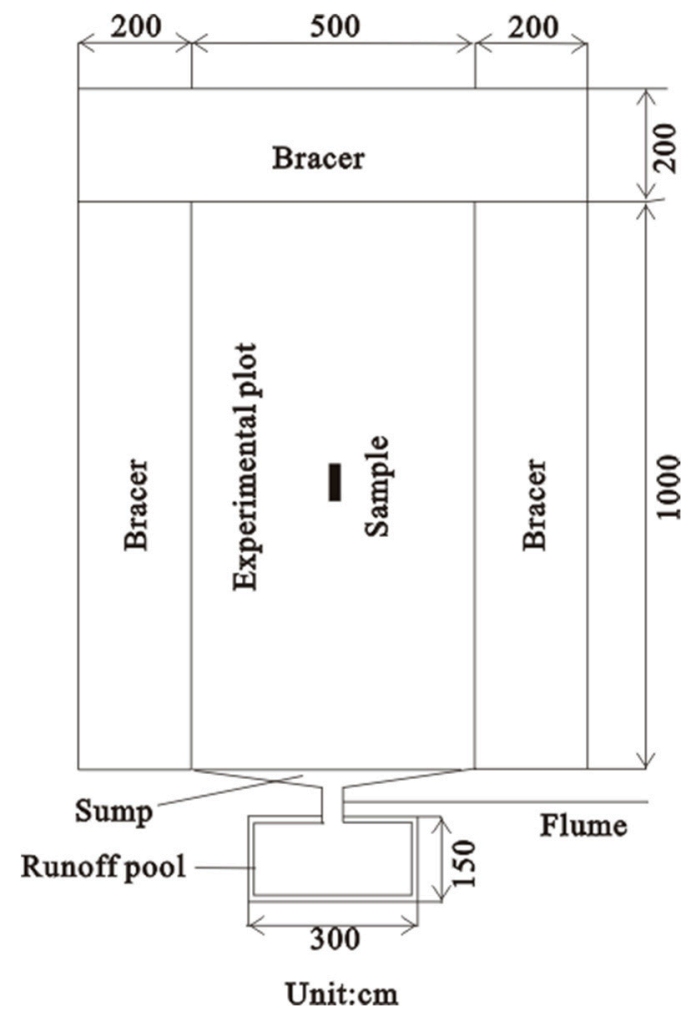

Figure 2. A diagram of the experimental plot.

\subsubsection{Soil Analysis}

An EGM-4 portable environmental gas detector (PP Systems, 110 Haverhill Road, Suite 301 Amesbury, MA, USA) was used to detect the soil $\mathrm{CO}_{2}$ concentration. The depth of the test was $15 \mathrm{~cm}$, according to the thickness of the soil layer. To avoid interference from other factors, the test points were selected uniformly. The soil $\mathrm{CO}_{2}$ test time was 9:00-11:00 a.m. because the study found that the soil $\mathrm{CO}_{2}$ content at this period could represent the average value for the whole day [24]. The soil $\mathrm{CO}_{2}$ content in the soil was measured by hammering a $2 \mathrm{~cm}$ diameter iron drill in the vertical direction at the test point. Starting from the surface, the soil $\mathrm{CO}_{2}$ content was measured at a depth of $15 \mathrm{~cm}$. After drilling to the specified depth, the iron rod was pulled out and the rubber hose connected to the inlet of the EGM-4 portable environmental gas detector was quickly inserted into the borehole. The maximum soil $\mathrm{CO}_{2}$ concentration readings were measured by the instrument after a short delay.

The soil samples were collected using the diagonal sampling method, and the soil samples taken at a depth of $0-15 \mathrm{~cm}$ at the four diagonals and the center were selected for mixing. The soil from all the sampling points was mixed together, and the roots, rocks and weeds were removed from the soil. The soil samples at oven temperature $100{ }^{\circ} \mathrm{C}$ were dried for $5 \mathrm{~h}$ after the removal of the moisture to constant weight for a particle size analysis. According to the size and distribution range of the tested samples, the sieves with different sizes and holes were stacked together for screening, the sieve 
allowance of each sieve was collected and the particle size distribution of the tested samples measured by weight was obtained by weighing. The range of granule grading was selected as $20 \mathrm{~mm}, 10 \mathrm{~mm}$, $5 \mathrm{~mm}, 1 \mathrm{~mm}, 0.5 \mathrm{~mm}, 0.25 \mathrm{~mm}, 0.1 \mathrm{~mm}$ and $0.075 \mathrm{~mm}$. After screening, the weight was measured and calculated, and finally the granule grading curve was obtained.

The soil sample was divided into two parts. One part, weighing approximately 10-20 g, was placed in a $4{ }^{\circ} \mathrm{C}$ refrigerated storage for soil microbial detection. For the part of the soil sample, PCR amplification was performed on the V4-V5 region of the $16 \mathrm{~S}$ rDNA of the sample bacteria [25]. The 5-5f and 907R primers were used (the primer sequences were $5^{\prime}$-GTGCCAGCMGCCGCGG-3' and 5'-CCGTCAATTCMTTTRAGTTT- $3^{\prime}$, respectively). The amplified fragment length was $392 \mathrm{bp}$; the RDP classifier Bayesian algorithm was used to cluster the sequences into $97 \%$ operational taxonomic units (OTUs) representative of sequences at similar levels, and the 563 OTU sequences were divided. The data were analyzed on the free online platform of Majorbio I-Sanger Cloud Platform (www.isanger.com). The amplification system, reaction conditions and data processing methods used are described in Sun et al. [26].

\subsubsection{Statistical Analysis}

The water samples were collected from four groups of plots under different land uses, and the water quality monitoring indexes measured included $\mathrm{pH}$; TDS; and the concentrations of $\mathrm{HCO}_{3}{ }^{-}, \mathrm{Cl}^{-}$, $\mathrm{NO}_{3}{ }^{-}, \mathrm{SO}_{4}{ }^{2-}, \mathrm{F}^{-}, \mathrm{Na}^{+}, \mathrm{K}^{+}, \mathrm{Mg}^{2+}$ and $\mathrm{Ca}^{2+}$. The SPSS 22.0 software was used to analyze the statistics and variations in the hydrochemical composition. A multivariate statistical analysis can be used as a quantitative method for groundwater classification to establish correlations between the chemical components of groundwater.

\subsubsection{Ion Proportional Coefficient Analysis}

The study of hydrogeochemistry, including the proportion coefficients of the components in hydrochemistry, can determine the source and formation of hydrochemical components. The $\gamma \mathrm{Mg}^{2+} / \gamma \mathrm{Ca}^{2+}$ and $\gamma \mathrm{Na}^{+} / \gamma \mathrm{Mg}^{2+}$ coefficients can reflect whether the ion exchange reaction occurs in the process by which groundwater quality evolve. The $\gamma \mathrm{Cl}^{-} / \gamma \mathrm{HCO}_{3}{ }^{-}$and $\gamma \mathrm{Cl}^{-} / \gamma \mathrm{SO}_{4}{ }^{2-}$ coefficients can reflect the variation in the component distribution during the evolution of groundwater.

\section{Results}

\subsection{Soil Granularity}

The sieving test was carried out on the soil samples, and the grain gradation curves for 4 groups of blocks were drawn (Figure 3). Reflecting the relative particle content in the soil samples, the degree of uniformity or gradation of particles in the soil samples can be roughly determined according to the slope of the particle gradation curve. If the curve is steep, this indicates that the particle sizes are similar and the particles are relatively uniform. If the curve is shallow, this indicates that the size of the particles varies greatly, the soil particles are not uniform and the gradation is strong. As shown in Figure 3, the curves for M01, M02 and M03 were similar but slightly steeper than that of M04, indicating that the distribution of soil particles in the block was relatively uniform. 

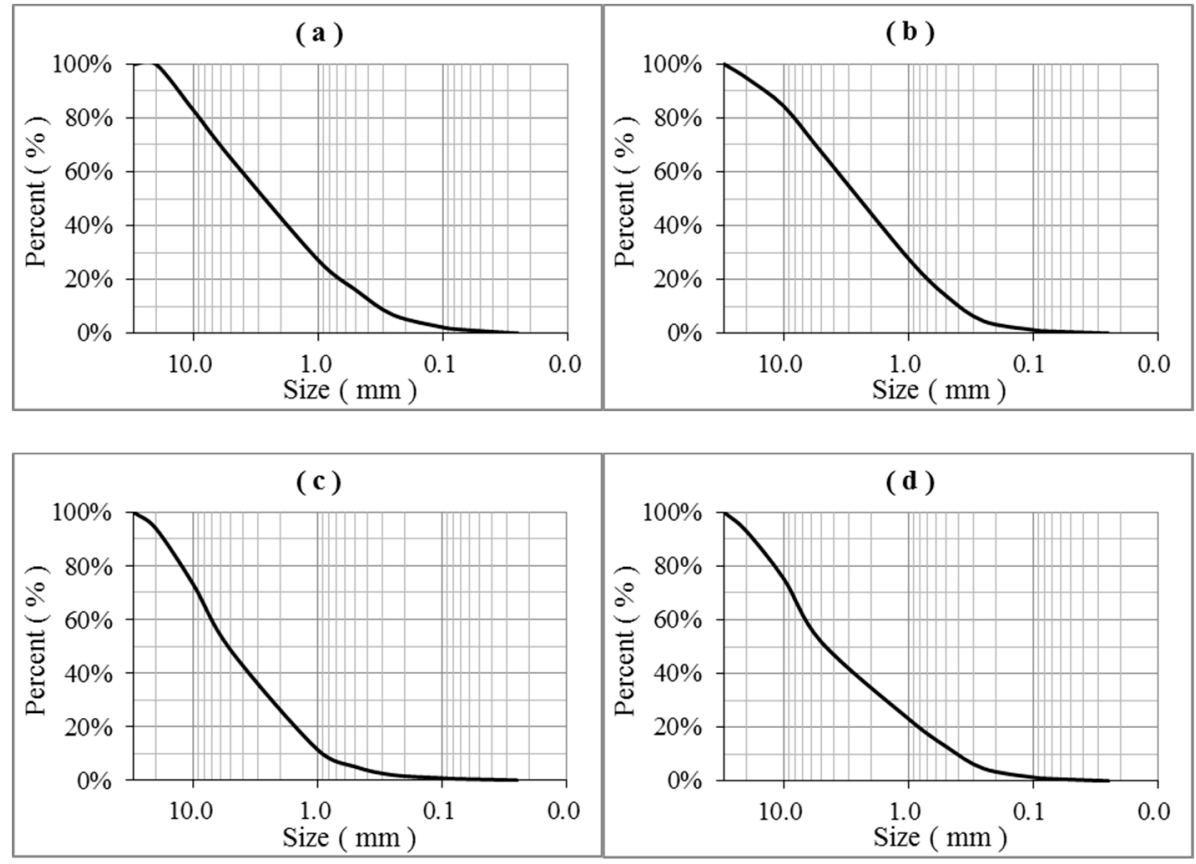

Figure 3. The particle gradation curves ((a) M01; (b) M02; (c) M03; (d) M04).

\subsection{Hydrochemical Characteristics}

\subsubsection{The Statistical Results}

A multivariate statistical analysis can be used as a quantitative method for groundwater classification to establish correlations between the chemical components of groundwater (Table 2). It can be seen from the hydrochemical statistical analysis table that the correlation between most ions is strong and that the correlation index between all of the ions is greater than 0.9. A low correlation was observed between $\mathrm{F}^{-}$ions and other ions. This indicates that there was a strong correlation between the major hydrochemical components from soil under different land uses, but the correlation between the microelement $\mathrm{F}^{-}$and other ions is low.

Table 2. The correlation of groundwater hydrochemical parameters.

\begin{tabular}{|c|c|c|c|c|c|c|c|c|c|c|c|}
\hline Ions & $\mathrm{pH}$ & TDS & $\mathrm{HCO}_{3}{ }^{-}$ & $\mathrm{Cl}^{-}$ & $\mathrm{NO}_{3}{ }^{-}$ & $\mathrm{SO}_{4}{ }^{2-}$ & $\mathbf{F}^{-}$ & $\mathrm{Na}^{+}$ & $\mathbf{K}^{+}$ & $\mathrm{Mg}^{2+}$ & $\mathrm{Ca}^{2+}$ \\
\hline $\mathrm{pH}$ & 1.00 & & & & & & & & & & \\
\hline TDS & 0.55 & 1.00 & & & & & & & & & \\
\hline $\mathrm{HCO}_{3}{ }^{-}$ & 0.54 & $0.98^{*}$ & 1.00 & & & & & & & & \\
\hline $\mathrm{Cl}^{-}$ & 0.46 & $0.97 *$ & 0.93 & 1.00 & & & & & & & \\
\hline $\mathrm{NO}_{3}{ }^{-}$ & 0.52 & $0.99^{* *}$ & $0.97^{*}$ & 0.99 * & 1.00 & & & & & & \\
\hline $\mathrm{SO}_{4}^{2-}$ & 0.50 & $0.99 * *$ & $0.99^{* *}$ & 0.96 * & $0.99 * *$ & 1.00 & & & & & \\
\hline $\mathrm{F}^{-}$ & 0.54 & -0.37 & -0.32 & -0.50 & -0.42 & -0.40 & 1.00 & & & & \\
\hline $\mathrm{Na}^{+}$ & 0.55 & $1.00^{* *}$ & $0.98^{*}$ & $0.97^{*}$ & $0.99^{* *}$ & $0.99 * *$ & -0.37 & 1.00 & & & \\
\hline $\mathrm{K}^{+}$ & 0.56 & $0.97^{*}$ & 0.93 & $0.99^{* *}$ & 0.98 * & 0.95 * & -0.39 & $0.97^{*}$ & 1.00 & & \\
\hline $\mathrm{Mg}^{2+}$ & 0.54 & $0.99 * *$ & $0.99 * *$ & $0.96 *$ & $0.99 * *$ & $0.99 * *$ & -0.37 & $0.99 * *$ & 0.96 * & 1.00 & \\
\hline $\mathrm{Ca}^{2+}$ & 0.56 & $0.99^{* *}$ & $0.99 * *$ & $0.97^{*}$ & $0.99 * *$ & $0.99 * *$ & -0.35 & $1.00 * *$ & 0.97 * & $0.99 * *$ & 1.00 \\
\hline
\end{tabular}

* The correlation is significant at the 0.05 level (two-tailed); ${ }^{* *}$ The correlation is significant at the 0.01 level (two-tailed).

\subsubsection{Hydrochemical Composition}

According to the variation curve of the hydrochemical index, there were obvious differences between the hydrochemical components in the plots under different land uses. Figure 4a shows that the $\mathrm{pH}$ of M01 was only 6.22, while the $\mathrm{pH}$ values of other groups were greater than that of 
M01. The concentrations of $\mathrm{NO}_{3}{ }^{-}, \mathrm{SO}_{4}{ }^{2-}, \mathrm{Cl}^{-}$and $\mathrm{HCO}_{3}{ }^{-}$ions in the water samples from $\mathrm{M} 03$ were significantly higher than those in the water samples from other plots and had concentrations of $3.41 \mathrm{mg} / \mathrm{L}, 11.6 \mathrm{mg} / \mathrm{L}, 1.46 \mathrm{mg} / \mathrm{L}$ and $49.8 \mathrm{mg} / \mathrm{L}$, respectively. The $\mathrm{F}^{-}$ion concentration was $0.157 \mathrm{mg} / \mathrm{L}$ in M01 and $0.562 \mathrm{mg} / \mathrm{L}$ in M04. As shown in Figure $4 \mathrm{~b}$, the concentrations of $\mathrm{K}^{+}, \mathrm{Na}^{+}$, $\mathrm{Ca}^{2+}$ and $\mathrm{Mg}^{2+}$ in cations showed the same trend. The cationic concentrations in $\mathrm{M} 03$ were the highest, at $5.57 \mathrm{mg} / \mathrm{L}, 2.03 \mathrm{mg} / \mathrm{L}, 25.3 \mathrm{mg} / \mathrm{L}$ and $4.54 \mathrm{mg} / \mathrm{L}$, respectively. As shown in Figure 4c, in M03, the TDS, total salinity and total hardness were all higher than those in the water samples from other plots. The concentrations of all the chemical components in the water samples from M01 were the lowest, and those from M03 were the highest except for $\mathrm{F}^{-}$, with M04 exhibiting the second highest concentrations of the chemical components in the water samples. This showed that land use had an influence on the chemical composition of the water. In non-vegetated land with low water chemical composition, the hydrochemical composition clearly increased when vegetation was planted. The concentrations of water chemicals in Castanea-planted land were significantly higher than those in a land with a different use. This indicated that Castanea planting has an obvious influence on groundwater quality.
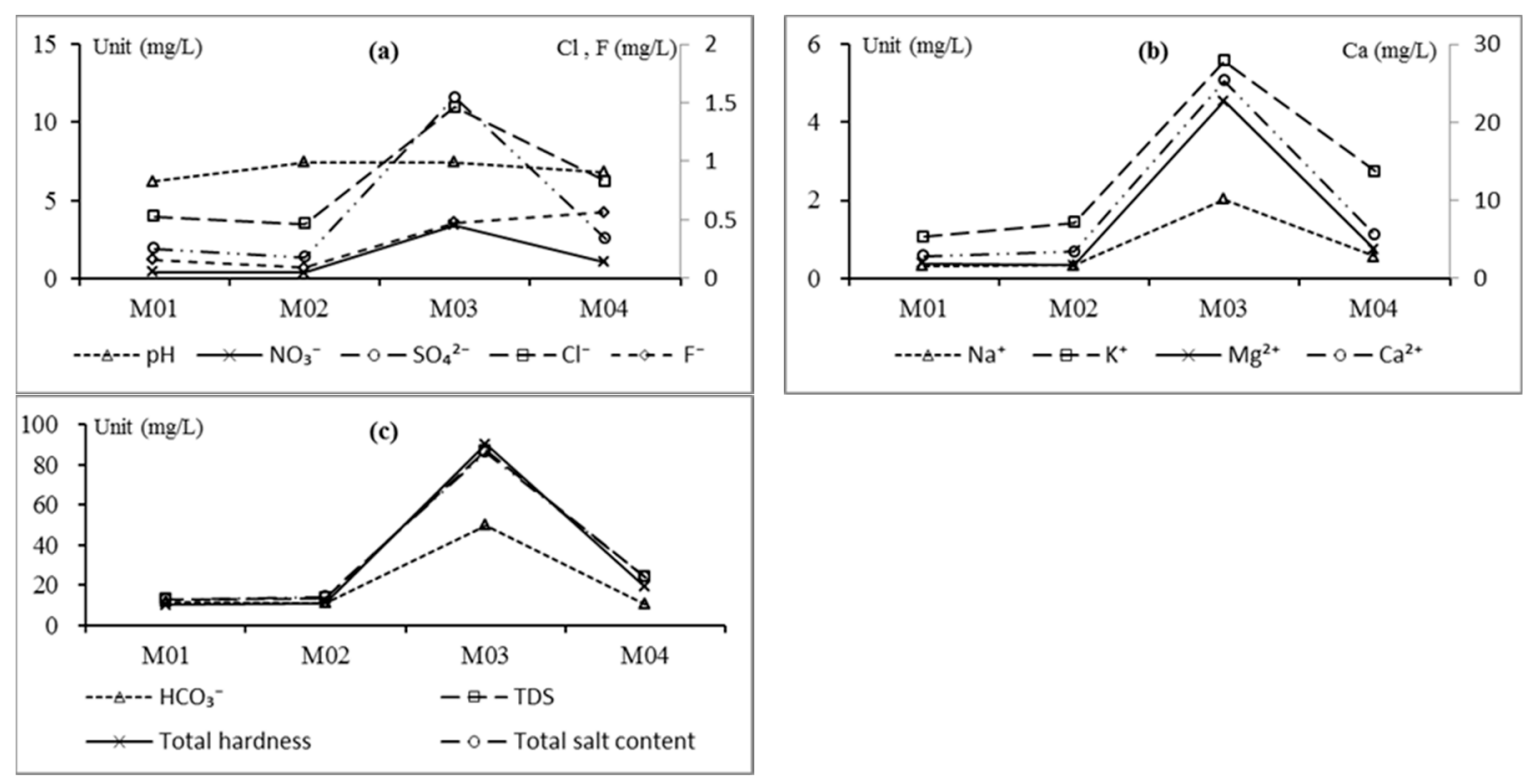

Figure 4. Changes in the concentrations of the main hydrochemical components of groundwater $((\mathbf{a}-\mathbf{c})$ represent the change in the content of each ion).

\subsubsection{Ion Proportional Coefficient}

The $\gamma \mathrm{Mg}^{2+} / \gamma \mathrm{Ca}^{2+}$ and $\gamma \mathrm{Na}^{+} / \gamma \mathrm{Mg}^{2+}$ coefficients can reflect whether the ion exchange reaction occurs in the process by which groundwater quality evolves. The $\gamma \mathrm{Cl}^{-} / \gamma \mathrm{HCO}_{3}{ }^{-}$and $\gamma \mathrm{Cl}^{-} / \gamma \mathrm{SO}_{4}{ }^{2-}$ coefficients can reflect the variation in the component distribution during the evolution of groundwater. If $\mathrm{SO}_{4}{ }^{2-}$ levels increase, sulfate dissolution may occur. Instead, sulfate reduction occurred. The change in $\mathrm{HCO}_{3}{ }^{-}$concentration can reflect the dissolution or precipitation of carbonate in water. As shown in Figure 5, $\gamma \mathrm{Mg}^{2+} / \gamma \mathrm{Ca}^{2+}$ was the smallest for M01 and the largest for M03. Additionally, the $\gamma \mathrm{Na}^{+} / \gamma \mathrm{Mg}^{2+}$ coefficient was the smallest for M03 and the largest for M02. The results showed that there was an obvious ion exchange reaction between $\mathrm{Na}^{+}$, and $\mathrm{Ca}^{2+}$ and $\mathrm{Mg}^{2+}$ in the presence of vegetation. When there was no vegetation, the ion exchange reaction was not obvious. As shown in Figure 5, the $\gamma \mathrm{Cl}^{-} / \gamma \mathrm{HCO}_{3}{ }^{-}$and $\gamma \mathrm{Cl}^{-} / \gamma \mathrm{SO}_{4}{ }^{2-}$ coefficients were the smallest for $\mathrm{M} 03$ and the largest for M04. This result indicated that sulfate reduction and carbonate dissolution may occur in M03, while sulfate dissolution and carbonate precipitation may occur in M04. The planting of Castanea affected the sulfate reduction process. The planting of pine tended to precipitate carbonate. Under bare land conditions, the levels of hydrochemical components were relatively stable. This further indicates that land use can affect hydrochemical composition. 


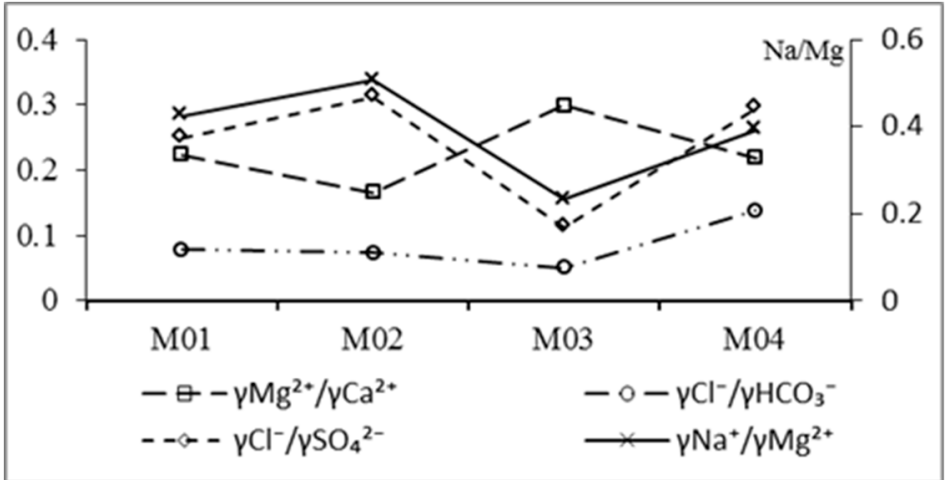

Figure 5. Changes in the proportional coefficients of hydrochemical ions.

\subsection{Soil Microbial Diversity}

Microbial diversity analysis is needed to verify whether the amount of sequencing data is sufficient to reflect the species diversity in a sample, and the dilution curve (species richness curve) can be used to test this indicator. The dilution curve was measured for $16 \mathrm{~S}$ rDNA sequences with known OTU ratios to calculate the extraction of $n$ ( $n$ is less than the number of total reads measured) reads when the expected OTU numbers were used. Then, based on a set of $n$ values (generally for a group of less than the total number of sequences) and the corresponding OTU numbers, the curve was generated. When the curve flattens out or reaches the plateau stage, the sequencing can be considered to have covered all species in the sample. This means that the species diversity in the sample is relatively high and that there are many species that have not been detected by sequencing [27]. As shown in Figure 6, the curves from different samples tend to flatten out, indicating that the selected samples cover a range of microorganisms, and to indicate the microbial diversity in each sample.

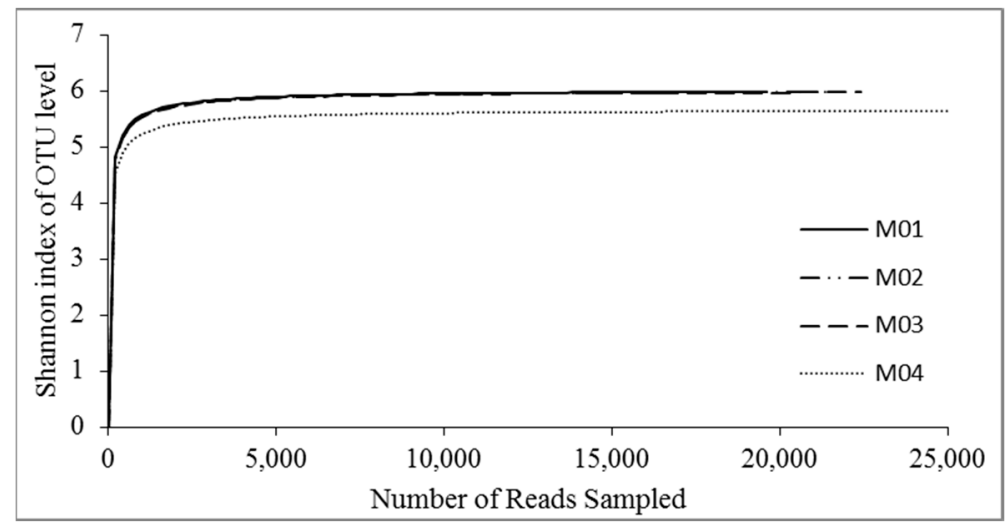

Figure 6. A sample microbial dilution curve.

In phylogenetic studies or population genetics studies, the OTU is the same marker artificially assigned to a taxon (line, species, genus, group, etc.) for the convenience of analysis. Sequences are usually divided into different OTUs based on $97 \%$ sequence similarity thresholds, and each OTU is generally considered to be a microbial species. If the sequence similarity between two organisms is less than $97 \%$, you can think of them as belonging to different species, and if the sequence similarity between two organisms is less than $93-95 \%$, you can think of them as belonging to different genera. The microbial diversity and abundance of different microorganisms in the samples were based on the analysis of OTUs. The RDP classifier Bayesian algorithm was used for the taxonomic analysis of $97 \%$ OTUs representing sequences at similar levels, and the community composition of each sample was statistically analyzed at various classification levels: Domain, Kingdom, Phylum, Class, Order, Family, Genus and Species. 


\subsubsection{Venn Diagram of Species}

A Venn diagram can be used to count the number of common and unique OTUs in multiple samples and can intuitively show the compositional similarity and difference between environmental samples at different classification levels. As shown in Figure 7, the numbers of core OTUs and unique OTUs in the four samples were 862 and 74, respectively. Among them, the M04 sample contained a total of 1188 OTUs, and the number of its unique OTUs was 27. The total number of OTUs in the M01 sample was 1105, and the number of unique OTUs was 24. The total number of OTUs in the M02 and M03 sample were 1171 and 1174, and the unique OTUs were 11 and 12, respectively. The microbial species in M04 and M01 were significantly different than those in the other two samples, and the microbial species in M02 and M03 were highly similar to one another. In these plots, there were few specific species. There were differences between the microbial species found in non-vegetated land and those found in vegetated land.
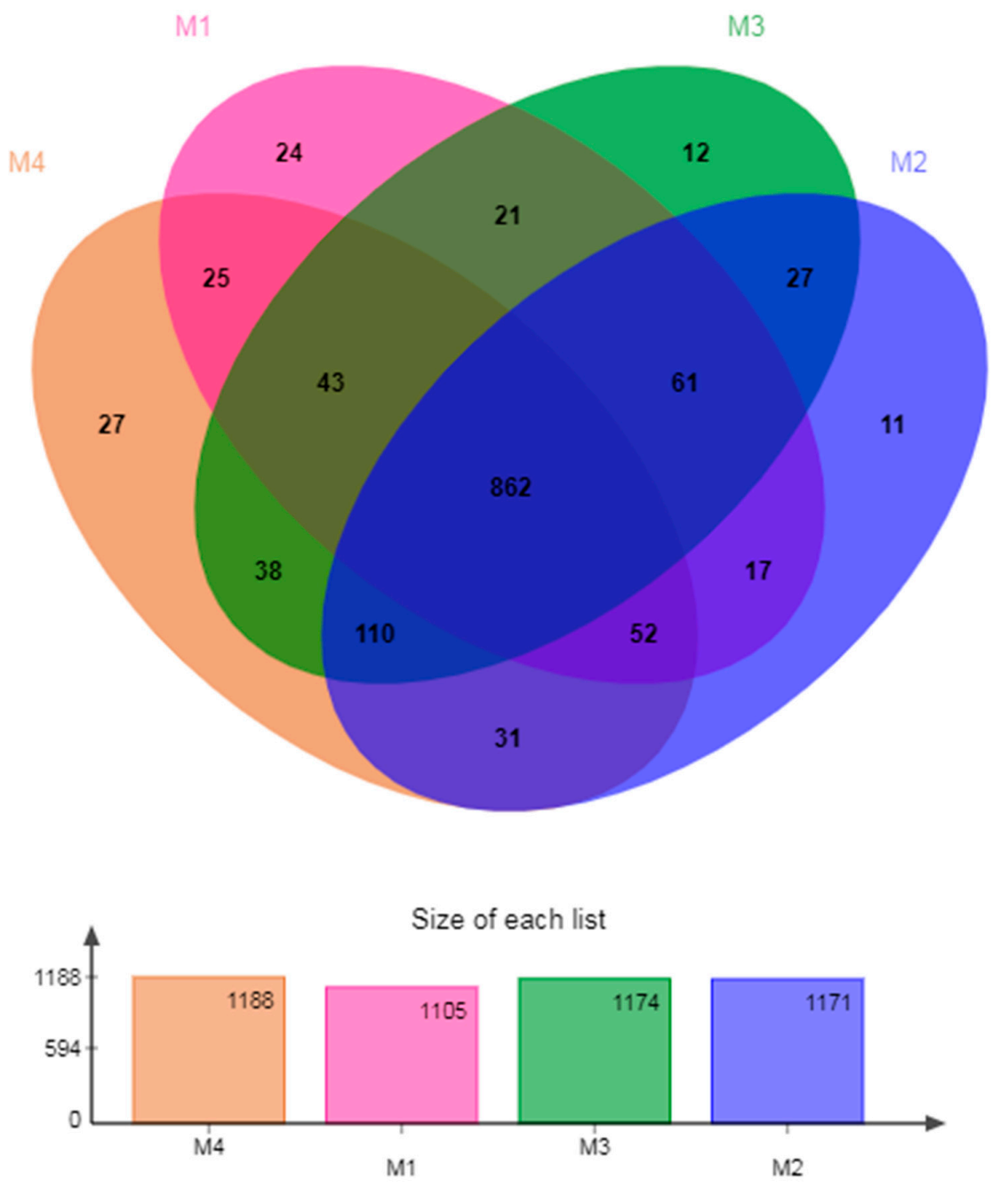

Number of elements: specific (1) or shared by $2,3, \ldots$ lists

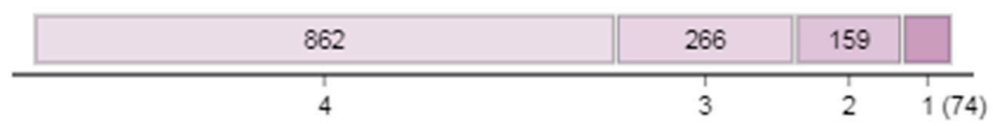

Figure 7. A Venn diagram of the operational taxonomic units (OTUs) for each sample. 


\subsubsection{Alpha Diversity}

Alpha diversity analyses, including the Chao1 index, Ace index, Shannon index and Simpson index [28,29], can show the community structure and diversity richness of microorganisms. First proposed by Chao (1984), the Chao1 index uses the Chao1 algorithm to estimate the number of OTUs in a community, and is often used in ecology to estimate the total number of species. The higher the Chao1 value is, the more species there are. The Ace index, also proposed by Chao, is used to estimate the number of OTUs in a community and is a commonly used index for estimating the total number of species in ecology; however, the Ace index is different from the Chao1 algorithm. The higher the Chao1 value or Ace value is, the higher the community richness is. The Simpson index is used to estimate the microbial diversity in samples. It was proposed by Edward Hugh Simpson (1949) and is often used to quantitatively describe the biological diversity of a region in ecology. The Shannon index, which can also be used to estimate microbial diversity in samples, and the Simpson index are commonly used to reflect the alpha diversity index. The higher the Shannon index or Simpson index is, the higher the microbial community diversity is. According to Table 3, there were differences between each index for the four samples. From M01 to M04, the Shannon index decreased gradually, while the Simpson index increased, indicating that community diversity decreased gradually and that the microbial diversity at M01 was the highest. From M01 to M04, the Chao index and Ace index first increase and then decrease. The Ace and Chao indexes were the highest for M02, indicating that microbial richness was the highest at $\mathrm{M} 02$ and the lowest at M01. Soil microbial diversity was relatively high in bare land. However, soil microbial richness was high in vegetated land.

Table 3. Bacterial diversity index.

\begin{tabular}{ccccc}
\hline Sample & Shannon & Simpson & Ace & Chao1 \\
\hline M01 & 5.992 & 0.004827 & 1207.113 & 1229.795 \\
M02 & 5.987 & 0.005312 & 1277.150 & 1301.102 \\
M03 & 5.981 & 0.005407 & 1260.625 & 1265.838 \\
M04 & 5.655 & 0.017962 & 1256.507 & 1274.106 \\
\hline
\end{tabular}

By analyzing the microbial richness of the samples, according to a $97 \%$ sequence similarity, the sequences were clustered as OTUs by software and a Phylum level microbial classification map was obtained. A total of 26 bacterial phyla, 60 bacterial classes and 351 genera were detected by sequencing, and those with a relative abundance less than 0.01 were merged into others. As shown in Figure 8, bacteria in each sample with different land uses mainly came from 12 phyla, among which Actinobacteria, Proteobacteria and Acidobacteria were the dominant bacteria. Chloroflexi, Nitrospirae, Gemmatimonadetes and Planctomycetes were subdominant bacteria. From the figure, it can be seen that from M01 to M04, the relative abundance of Actinobacteria was 0.25, 0.31, 0.32 and 0.36 , respectively. The relative abundance of Proteobacteria was $0.28,0.27,0.25$ and 0.28 , respectively, for M01 to M04. Acidobacteria were $0.18,0.17,0.16$ and 0.15 in relative abundance from M01 to M04. The relative abundance of subdominant bacteria ranged from $0.03-0.07$, and the content of other bacteria was lower. The Proteobacteria content was the highest in M01, and the Actinobacteria content was the highest in M02, M03 and M04. The planting of vegetation increased the Actinobacteria content in the soil, and the amplitude of this increase was different with different types of vegetation. However, the Proteobacteria content was mainly affected by bare land. In M01, in addition to the dominant and subdominant phyla, the relative abundances of unclassified_k_norank (indicating undetected bacterial phyla) and Firmicutes were significantly higher than those in other groups. In M04, the relative abundances of unclassified_k__norank and Firmicutes bacteria were only 0.009 and 0.01 , respectively. The Deinococcus-thermus species were only found in M01, and Saccharibacteria appeared in M04. Nitrophica were found in small amounts numbers in M02, M03 and M04. This result indicated that there were unique microbial species in the bare land and that unique microbial species were also found in the vegetated land. There were differences in the specific microbial species and 
their relative content among different vegetation types. The results showed that land use could change the content of the dominant microflora of the soil and decrease or increase unique microflora.

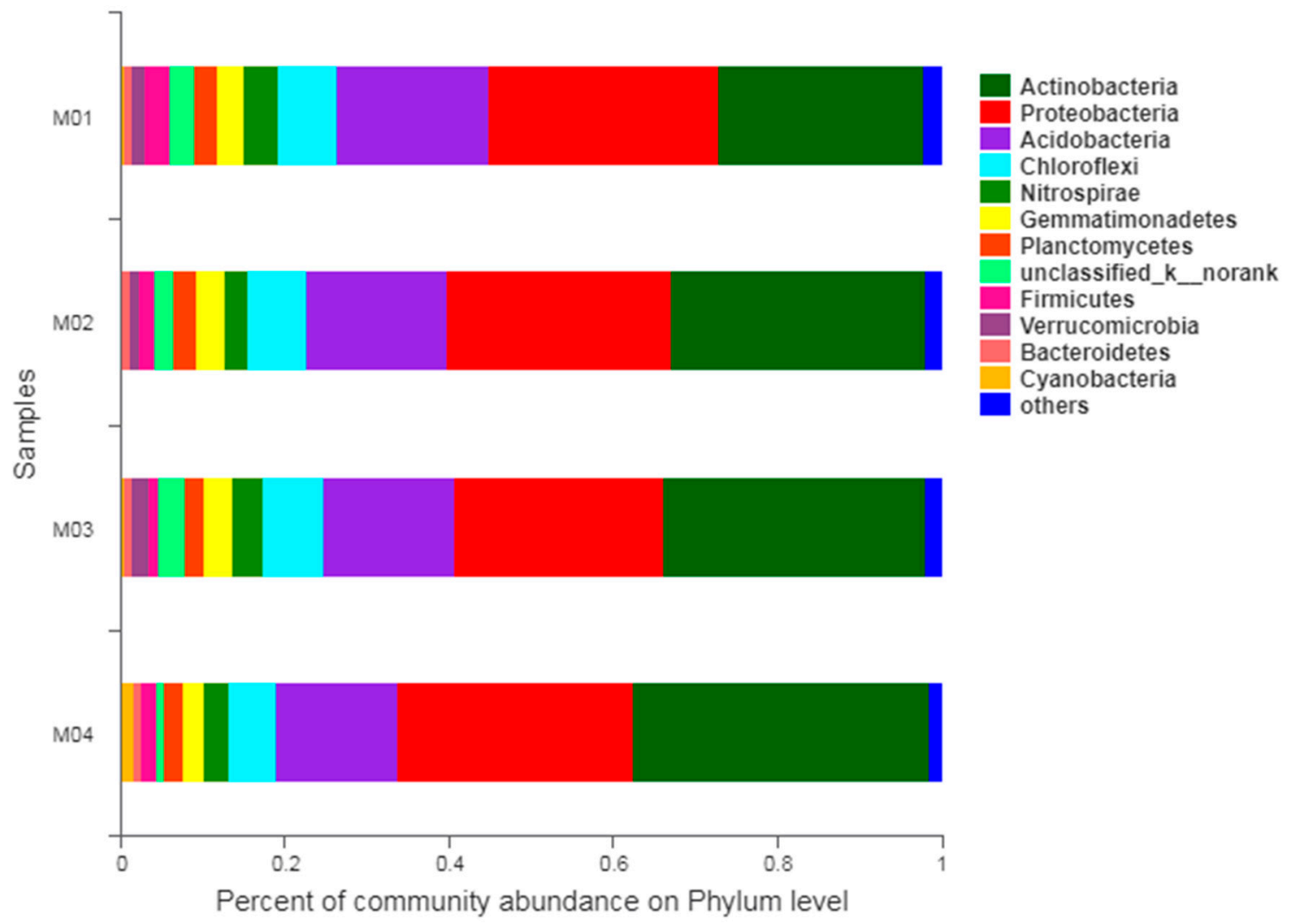

Figure 8. The phylum level of soil microorganism under different land uses.

\section{Discussion}

\subsection{Soil $\mathrm{CO}_{2}$}

Before collecting the soil samples, the atmospheric and soil carbon dioxide levels were detected. The test results are shown in Table 4. The atmospheric carbon dioxide content was only $450 \mathrm{mg} / \mathrm{m}^{3}$, which is significantly less than the soil carbon dioxide content. However, the soil carbon dioxide content in bare land (M01) was lower than that in the other plots, and the Castanea-containing land (M03) had the highest soil carbon dioxide content. This indicates that there were some differences in the soil carbon dioxide content in plots under different land uses.

Table 4. The carbon dioxide content.

\begin{tabular}{cccccc}
\hline Sample & Atmosphere & M01 & M02 & M03 & M04 \\
\hline $\mathrm{CO}_{2}\left(\mathrm{mg} / \mathrm{m}^{3}\right)$ & 450 & 1863 & 2005 & 3059 & 2561 \\
\hline
\end{tabular}

Soil $\mathrm{CO}_{2}$ is derived from the respiration of soil microorganisms, the respiration of root systems, the respiration of soil animals and the oxidation of carbonaceous minerals [30]. Therefore, soil microbes can affect the amount of carbon dioxide in the soil. As is well-known, $\mathrm{CO}_{2}$ gas exists in the soil and should meet the general law of gas movement, including the following formula:

$$
\frac{\partial C}{\partial t}=D \frac{\partial^{2} C}{\partial x^{2}}-v \frac{\partial C}{\partial x}
$$


where $\mathrm{C}$ is the $\mathrm{CO}_{2}$ concentration, $\mathrm{D}$ is the $\mathrm{CO}_{2}$ diffusion coefficient, $\mathrm{V}$ is the velocity of gas migration, $\mathrm{T}$ is time, $\mathrm{X}$ is the vertical distance and $\mathrm{W}$ is the other source of $\mathrm{CO}_{2}$. The effect of temperature on $\mathrm{CO}_{2}$ is not considered by the analysis of the results of this study. Other sources of $\mathrm{CO}_{2}(\mathrm{~W})$ include soil microbial activity, the absorption or release of animal and plant respired $\mathrm{CO}_{2}$, chemical reactions, and water and other substances with $\mathrm{CO}_{2}$. After a long time, the velocity of gas migration in the equation $(\mathrm{V})$ remains unchanged and the movement of gas maintains dynamic balance. The soil and the $\mathrm{CO}_{2}$ dispersion coefficient (D) parameters, which depend on the physical properties of the gas and the soil itself, will not change in the short term. If the $\mathrm{CO}_{2}$ source (W) does not cause interference, after a sufficiently long time, the system will reach an equilibrium state. The final $\mathrm{CO}_{2}$ concentration (C) is only related to the soil depth $(\mathrm{X})$, and the depth of the $\mathrm{CO}_{2}$ remains unchanged. This study collected soil samples from the same depth and found that there were significant differences in soil $\mathrm{CO}_{2}$. The main reason for this is that microorganisms in different soil samples changed $\mathrm{W}$ and made the soil $\mathrm{CO}_{2}$ concentrations different.

\subsection{Soil $\mathrm{CO}_{2}$ and Soil Microbial}

Soil is an important part of the ecosystem. As an important natural resource, it maintains the health of terrestrial ecosystems and plays an important role in the circulation of materials and energy flow of ecosystems [31]. The amount of carbon released into the atmosphere by the microbial decomposition of soil organic carbon is approximately $68-100$ pg every year, accounting for approximately $10 \%$ of atmospheric $\mathrm{CO}_{2}$ reserves [32]. Therefore, soil microbial changes play an important role in the carbon cycle. As the main form of human disturbance, land use is the key factor affecting the terrestrial ecosystem. Different land uses can change the proportion of solid, liquid and gas in soil [33], affect soil microbial biomass and activity [34], and then affect the $\mathrm{CO}_{2}$ flux released from the soil to the atmosphere [35]. Soil microbial richness and diversity are important indexes of soil ecological function. In the long-term evolutionary process, species have formed relatively stable adaptive relationships with each other and with the environment that may be broken down by changes in land use patterns, thus changing the composition and diversity of soil microbial communities [36]. Chapman et al. found that after a change in the use of natural forestland, soil microbial diversity also changed [37]. Griffiths et al. showed that soil microorganisms have a certain resistance and resilience to environmental changes, especially changes in soil community richness and diversity [38]. In contrast, some scholars found that land use had no effect on soil microbial diversity [22]. Kuntz et al. also found that farming methods had no significant impact on the microbial diversity [39]. In the current study, it was found that land use had an impact on microbial diversity. Whether land is vegetated or not, soil microorganisms have obvious similarities and differences (Figures 7 and 8). It was found by observing the soil $\mathrm{CO}_{2}$ content (Table 3) that the soil $\mathrm{CO}_{2}$ content followed the trend of $\mathrm{M} 03>\mathrm{M} 04>\mathrm{M} 02>\mathrm{M} 01$. The $\mathrm{CO}_{2}$ levels of these plots were much higher than the carbon dioxide content in the atmosphere. Some scholars have found similar results [40]. Through the analysis of microbial diversity, it was found that the microbial phyla in the soil were mainly Actinobacteria, Proteobacteria and Acidobacteria. Actinomycetes are usually distributed in the soil, and most of them are aerobic bacteria that, with good air quality, can produce $\mathrm{CO}_{2}$.

\subsection{The $\mathrm{CO}_{2}$ and Water Quality}

$\mathrm{CO}_{2}$ is slightly soluble in water and is present as $\mathrm{CO}_{2}(\mathrm{aq}), \mathrm{H}_{2} \mathrm{CO}_{3}, \mathrm{HCO}_{3}{ }^{-}$and $\mathrm{CO}_{3}{ }^{2-}$ in water. $\mathrm{H}_{2} \mathrm{CO}_{3}$ accounts for only approximately $1 \%$ of the total amount of $\mathrm{CO}_{2}$. The content of carbonic acid in aqueous solution mainly depends on the partial pressure of $\mathrm{CO}_{2}$, the $\mathrm{pH}$ of the aqueous solution and the chemical composition. In the process of the infiltration of precipitation through the soil layer, a water-rock reaction will occur, resulting in hydrochemical changes. When the $\mathrm{CO}_{2}$ content in soil increases, the dissolved $\mathrm{CO}_{2}$ in water correspondingly increases and combines with $\mathrm{H}_{2} \mathrm{O}$ to form $\mathrm{H}_{2} \mathrm{CO}_{3}$, which is then decomposed into $\mathrm{H}^{+}$and $\mathrm{HCO}_{3}{ }^{-}$to form a new balance. Wang $\mathrm{X}$ et al. found that the trend of changes in the $\mathrm{Ca}^{2+}$ and $\mathrm{HCO}_{3}{ }^{-}$concentrations was basically the same as that of 
the soil $\mathrm{CO}_{2}$ concentration, while the trend of $\mathrm{pH}$ value changes was opposite to that of the soil $\mathrm{CO}_{2}$ concentration [41]. Cao et al. also found a negative correlation between $\mathrm{CO}_{2}$ concentration and $\mathrm{pH}$ in the liquid phase of a cave [42]. After $\mathrm{CO}_{2}$ is injected into the ground, a phase equilibrium reaction occurs, which reduces the $\mathrm{pH}$ value of the water in the formation, thus changing the balance between the existing salt water in the formation and the rock, resulting in mineral dissolution or precipitation in the rock layer [43]. In conclusion, the amount of soil $\mathrm{CO}_{2}$ content can affect the chemical composition of the water. Table 3 and Figure 4 show that the respective $\mathrm{K}^{+}, \mathrm{Na}^{+}, \mathrm{Ca}^{2+}$ and $\mathrm{Mg}^{2+}$ and $\mathrm{NO}_{3}{ }^{-}, \mathrm{SO}_{4}{ }^{2-}$, $\mathrm{Cl}^{-}$and $\mathrm{HCO}_{3}{ }^{-}$concentrations follow the same trend as that seen for soil $\mathrm{CO}_{2}$ concentration, and all of the ions increase in concentration with the increase of increasing soil $\mathrm{CO}_{2}$ content. This is similar to the research results from most scholars. However, the change of $\mathrm{F}^{-}$content is different from that of $\mathrm{CO}_{2}$, and a negative correlation between $\mathrm{pH}$ change and soil $\mathrm{CO}_{2}$ was not detected.

\subsection{Correlation between Soil $\mathrm{CO}_{2}$, Hydrochemical and Soil Microbial}

Through a preliminary analysis, it was found that soil $\mathrm{CO}_{2}$ content, water chemical composition and soil microbial community composition were different under different land uses. What are the reasons for this phenomenon? What is the correlation between these factors? To better understand the correlation between them, the hydrochemical compositions and soil $\mathrm{CO}_{2}$ were selected to discuss the correlation between different environmental factors and soil microbial species. A heatmap was used to analyze the results, and the correlation coefficients between environmental factors and microorganisms were calculated (Figure 9). The $x$-axis and $y$-axis represent environmental factors and species, respectively, and the R-values and P-values were obtained through calculation and were used to represent the correlation coefficient between each microorganism in the community and each variable environmental factor variable. The R-values are shown in different colors in the figure (Red means a positive correlation, and blue means negative correlation. The darker the color, the higher the correlation.), and the P-values are represented by the value size (Integrity means a positive correlation, and negative means a negative correlation. The better the correlation is, the higher the value is.). The figure on the right is the color interval for different $\mathrm{R}$ - and P-values of different sizes.

Based on the relative abundance map of bacterial phyla, the relationship between environmental factors and the 12 phyla was considered. Figure 9 shows that soil microorganisms are different under the influence of different environmental factors. There were different correlations between the hydrochemical composition, soil $\mathrm{CO}_{2}$ content and bacteria. The influence of $\mathrm{pH}$ on the bacterial phyla is complex, and the $\mathrm{pH}$ shows a low correlation with the dominant phylum but a significant negative correlation with Firmicutes (the P-value is -0.853). Except for Firmicutes, soil $\mathrm{CO}_{2}$ is positively correlated with bacteria, with a slightly higher correlation between soil $\mathrm{CO}_{2}$ with the subdominant bacteria. The $\mathrm{F}^{-}$ion concentration was positively correlated with the dominant microflora and the subdominant microflora and negatively correlated with Firmicutes and Verrucomicrobia with P-values of -0.185 and -0.202 , respectively. The relative abundance of Planctomycetes is negatively related to $\mathrm{HCO}_{3}{ }^{-}, \mathrm{Cl}^{-}, \mathrm{NO}_{3}{ }^{-}$and $\mathrm{SO}_{4}{ }^{2-}$ concentrations, whereas ions are positively correlated with the abundance of other bacterial phyla. TDS shows a general correlation with the dominant and subdominant bacteria but a significantly negative correlation with Firmicutes. However, the $\mathrm{K}^{+}, \mathrm{Na}^{+}, \mathrm{Ca}^{2+}$ and $\mathrm{Mg}^{2+}$ concentrations were slightly less correlated with the dominant bacteria and the subdominant bacteria. The overall correlation between Actinobacteria and the 12 phyla was neutral, and there was only a significant positive correlation between the Actinobacteria and $\mathrm{F}^{-}$ion concentrations. Proteobacteria and Acidobacteria were related to similar environmental factors as Actinobacteria with different land use. Nitrospirae and Chloroflexi showed a positive correlation with the major soil anions, but the correlation coefficient was small. However, they showed a strong correlation with soil $\mathrm{CO}_{2}$. Gemmatimonadetes was significantly positively correlated with hydrochemistry and the soil $\mathrm{CO}_{2}$ content, and the P-value with the soil $\mathrm{CO}_{2}$ was 0.836 . There is little correlation between Planctomycetes and environmental factors, and these bacteria are negatively 
correlated with $\mathrm{HCO}_{3}{ }^{-}$, with a P-value of -0.507 , and positively correlated with $\mathrm{F}^{-}$, with a P-value of 0.496. In addition, Firmicutes showed a strong negative correlation with various environmental factors.

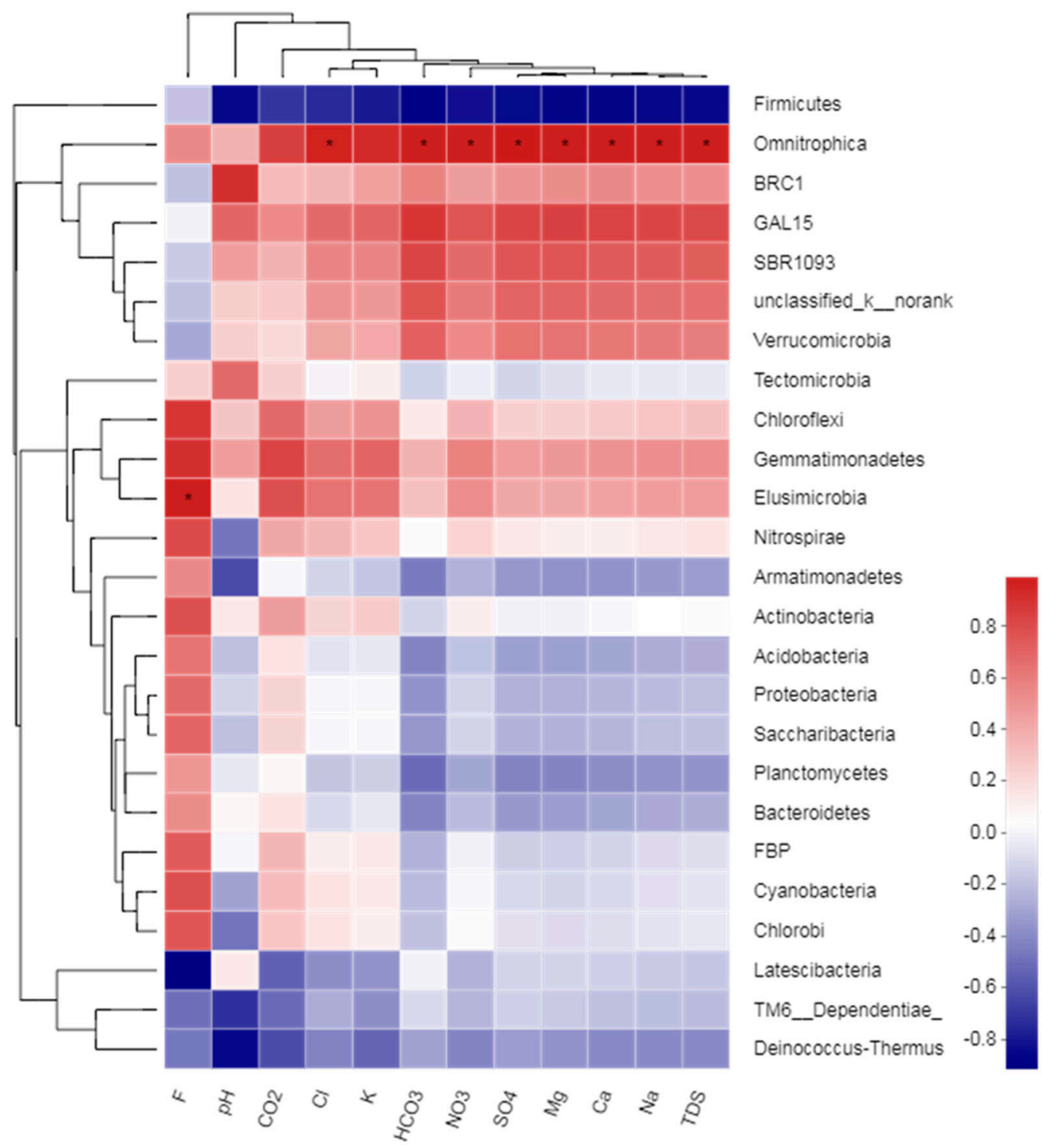

Figure 9. The correlation between microorganisms and environmental factors (* The correlation is significant at the 0.05 level; ${ }^{* *}$ The correlation is significant at the 0.01 level).

Under different types of land uses, microorganisms can change soil $\mathrm{CO}_{2}$ content, while soil $\mathrm{CO}_{2}$ content can influence water chemical composition. In contrast, different water chemical compositions can also affect soil microbial diversity, and soil microbes can further change soil $\mathrm{CO}_{2}$ content. In a word, under different types of land uses, soil $\mathrm{CO}_{2}$ content, water chemical composition and soil microorganisms all changed and influenced one another. This shows that the impact of land use on biodiversity is complex, and the hydrochemical change process is also a complex process, but it can be verified and correlated by soil $\mathrm{CO}_{2}$ content.

\section{Conclusions}

In this research, Laiwu, an important agriculture area, was studied to understand the influence of land use, which was considered to be important for healthy ecosystem management. This study evaluated the potential impact of $\mathrm{CO}_{2}$ influx for hydrochemistry and microorganisms. Further research should be conducted to confirm and quantify the impact. 
The results show that vegetation forms can influence the water chemistry compositions. Different hydrochemical indices between vegetated and non-vegetated areas suggested that land-use patterns can affect the evolution of water chemical composition. Furthermore, we found that microbial diversities are variable with vegetation forms. A non-vegetated area has seen the highest microbial diversity and the lowest abundance, while the microbial diversity and abundance were mainly related to the vegetation in vegetation area. Soil $\mathrm{CO}_{2}$ content was related to both microbe communities and water compositions. It may give hints that $\mathrm{CO}_{2}$ flux was influence by land use and then may influence the groundwater chemistry compositions and microbe communities development in soil.

Author Contributions: Conceptualization, Z.G.; data curation, H.Z.; formal analysis, H.Z. and M.S.; investigation, H.Z., M.S., S.F., Y.C., H.X. and J.L.; methodology, Z.G., H.Z. and M.S.; project administration, Z.G.; resources, H.Z. and M.S.; writing-original draft, H.Z. All authors read and approved the final manuscript.

Funding: National Natural Science Foundation of China (41641022).

Acknowledgments: Our thanks are extended to the National Natural Science Foundation of China (41641022) and to the China Geological Survey (1212012000150003), and this study was successfully completed and supported by the office of soil and water conservation of Laiwu, Ministry of water resources.

Conflicts of Interest: The authors declare no conflict of interest.

\section{References}

1. Lee, S.W.; Hwang, S.J.; Lee, S.B.; Hwang, H.S.; Sung, H.C. Landscape ecological approach to the relationships of land use patterns in watersheds to water quality characteristics. Landsc. Urban Plan. 2009, 92, 80-89. [CrossRef]

2. Tran, C.P.; Bode, R.W.; Smith, A.J.; Kleppel, G.S. Land-use proximity as a basis for assessing stream water quality in New York State (USA). Ecol. Indic. 2010, 10, 727-733. [CrossRef]

3. Kang, J.H.; Lee, S.W.; Cho, K.H.; Ki, S.J.; Cha, S.M.; Kim, J.H. Linking land-use type and stream water quality using spatial data of fecal indicator bacteria and heavy metals in the Yeongsan river basin. Water Res. 2010, 44, 4143-4157. [CrossRef] [PubMed]

4. Don, A.; Kalbitz, K. Amounts and degradability of dissolved organic carbon from foliar litter at different decomposition stages. Soil Biol. Biochem. 2005, 37, 2171-2179. [CrossRef]

5. Schoonover, J.E.; Lockaby, B.G. Land cover impacts on stream nutrients and fecal coliform in the lower Piedmont of West Georgia. J. Hydrol. 2006, 331, 371-382. [CrossRef]

6. Stutter, M.I.; Langan, S.J.; Demars, B.O.L. River sediments provide a link between catchment pressures and ecological status in a mixed land use Scottish River system. Water Res. 2007, 41, 2803-2815. [CrossRef] [PubMed]

7. Bronstert, A.; Niehoff, D.; Bürger, G. Effects of climate and land-use change on storm runoff generation: Present knowledge and modelling capabilities. Hydrol. Process. 2002, 16, 509-529. [CrossRef]

8. Jiang, Y.-J.; Yuan, D.-X.; Zhang, G.; He, R.-S. Effect of land use change on griundwater quality in karst watershed-A case study in Xiaojiang water of Yunnan province. J. Nat. Resour. 2004, 19, 707-715.

9. Jia, Y.; Yuan, D.-X.; He, D. A study on the relationship between land use change and karst groundwater quality. J. Southwest China Norm. Univ. (Nat. Sci.) 2006, 31, 167-171.

10. Guo, F.; Jiang, G.-H.; Xia, Q.; Li, K. Hydro-chemical variation of karst groundwater under the impact of land use in Donghe catchment, Hunan. Carsologica Sin. 2007, 26, 212-218.

11. Wang, J.; Zhang, F.; Zhang, Y.; Ren, Y.; Yue, H.Y. Correlation between the spatial water quality and land use /cover in the Ebinur Lake area. Acta Ecol. Sin. 2016, 36, 7971-7980.

12. Tu, J. Spatially varying relationships between land use and water quality across an urbanization gradient explored by geographically weighted regression. Appl. Geogr. 2011, 31, 376-392. [CrossRef]

13. Duan, S.; An, Y.; Su, X.; Wu, Q.; Jin, T.; Yiliang, H.; Wu, J. Effect of multi-scale land use on water quality in Sancha river. Environ. Pollut. Control 2017, 39, 525-529.

14. Zhang, M.; Wang, Z.; Li, K.; Chen, J.; Cao, W.; Li, S.; Zi, H.; Huang, X.; Deng, Y. Spatial and seasonal geochemical chaeacteristics of shallow groundwater in response to land use in Guangzhou. Ecol. Environ. Sci. 2017, 26, 1539-1546. [CrossRef] 
15. Narany, T.S.; Aris, A.Z.; Sefie, A.; Keesstra, S. Detecting and predicting the impact of land use changes on groundwater quality, a case study in Northern Kelantan, Malaysia. Sci. Total Environ. 2017, 599-600, 844-853. [CrossRef] [PubMed]

16. Bi, M.; Yu, W.; Jiang, Z.; Ma, Q.; Zhang, L.; Xu, Y. Study on the Effects of Different Land Use Patterns on Microbial Community Structure in Aquic Brown Soil by Utilizing PLFA Method. Sci. Agric. Sin. 2010, 43, 1834-1842.

17. Mäder, P.; Berner, A. Development of reduced tillage systems in organic farming in Europe. Renew. Agric. Food Syst. 2012, 27, 7-11. [CrossRef]

18. Sun, B.; Hallett, P.D.; Caul, S.; Daniell, T.J.; Hopkins, D.W. Distribution of soil carbon and microbial biomass in arable soils under different tillage regimes. Plant Soil 2011, 338, 17-25. [CrossRef]

19. Poulsen, P.H.B.; Magid, J.; Luxhøi, J.; Neergaard, A.D. Effects of fertilization with urban and agricultural organic wastes in a field trial-Waste imprint on soil microbial activity. Soil Biol. Biochem. 2013, 57, 784-793. [CrossRef]

20. Goss-Souza, D.; Mendes, L.W.; Borges, C.D.; Baretta, D.; Tsai, S.M.; Jlm, R. Soil microbial community dynamics and assembly under long-term land use change. FEMS Microbiol. Ecol. 2017, 93. [CrossRef] [PubMed]

21. Deng, J.-J.; Zhu, W.-X.; Zhou, Y.-B.; Yin, Y.; Bai, X.-J.; Zhang, H.-Z.; Zhang, Y.-M.; Qin, S.-J. Effect of different land use patterns on the soil microbial community diversity in montane region of eastern Liaoning province, China. Chin. J. Appl. Ecol. 2018, 29, 2269-2276.

22. Li, L.-N.; Xi, Y.-G.; Chen, E.; He, L.-P.; Wang, L.; Xiao, X.-J.; Tian, W. Effects of tillage and green manure crop on composition and diversity of soil microbial community. J. Ecol. Rural Environ. 2018, 34, 342-348.

23. Liu, L.J.; Li, X.Y.; He, X.Y. Advances in the study of the relationship between landscape pattern and river water quality at the watershed scale. Acta Ecol. Sin. 2011, 31, 5460-5465.

24. Javed, I.; Hu, R.; Feng, M.; Lin, S.; Saadatullah, M.; Ibrahimmohamed, A. Microbial biomass, and dissolved organic carbon and nitrogen strongly affect soil respiration in different land uses: A case study at Three Gorges Reservoir Area, South China. Agric. Ecosyst. Environ. 2010, 137, 294-307. [CrossRef]

25. Xu, N.; Tan, G.; Wang, H.; Gai, X. Effect of biochar additions to soil on nitrogen leaching, microbial biomass and bacterial community structure. Eur. J. Soil Biol. 2016, 74, 1-8. [CrossRef]

26. Sun, J.; Zhang, Q.; Zhou, J.; Wei, Q. Pyrosequencing technology reveals the impact of different manure doses on the bacterial community in apple rhizosphere soil. Appl. Soil Ecol. 2014, 78, 28-36. [CrossRef]

27. Schloss, P.D.; Westcott, S.L.; Thomas, R.; Hall, J.R.; Martin, H.; Hollister, E.B.; Lesniewski, R.A.; Oakley, B.B.; Parks, D.H.; Robinson, C.J. Introducing mothur: Open-source, platform-independent, community-supported software for describing and comparing microbial communities. Appl. Environ. Microbiol. 2009, 75, 7537. [CrossRef] [PubMed]

28. Hui, L.; Ye, D.; Wang, X.; Settles, M.L.; Wang, J.; Hao, Z.; Zhou, L.; Ping, D.; Yong, J.; Ma, Z. Soil bacterial communities of different natural forest types in Northeast China. Plant Soil 2014, 383, 203-216.

29. Sengupta, A.; Dick, W.A. Bacterial Community Diversity in Soil Under two Tillage Practices as Determined by Pyrosequencing. Microb. Ecol. 2015, 70, 853-859. [CrossRef] [PubMed]

30. Tamir, G.; Shenker, M.; Heller, H.; Bloom, P.R.; Fine, P.; Bar-Tal, A. Dissolution and Re-crystallization Processes of Active Calcium Carbonate in Soil Developed on Tufa. Soil Sci. Soc. Am. J. 2012, 76, 1606. [CrossRef]

31. Westerdahl, B. Biological Control of Plant-Parasitic Nematodes: Soil Ecosystem Management in Sustainable Agriculture, Second Edition. Soil Sci. Soc. Am. J. 2015, 79, 972. [CrossRef]

32. James, W.R.; Christopher, S.P.; Dwipen, B. Intrtannual variability in global soil respirtion, 1980-1994. Glob. Chang. Biol. 2002, 8, 800-812.

33. Carrera, M.A.; Marques, M.J.; Carral, P.; Alvarez, A.M.; López, C.; Martín-López, B.; González, J.A. Impacts of land-use intensity on soil organic carbon content, soil structure and water-holding capacity. Soil Use Manag. 2013, 29, 547-556. [CrossRef]

34. Kara, O.; Baykara, M. Changes in soil microbial biomass and aggregate stability under different land uses in the northeastern Turkey. Environ. Monit. Assess. 2014, 186, 3801-3808. [CrossRef] [PubMed]

35. Fuchs, R.; Schulp, C.J.; Hengeveld, G.M.; Verburg, P.H.; Clevers, J.G.; Schelhaas, M.J.; Herold, M. Assessing the influence of historic net and gross land changes on the carbon fluxes of Europe. Glob. Chang. Biol. 2016, 22, 2526-2539. [CrossRef] [PubMed] 
36. Ren, Y.G.; Li, T.C.; Ju, Z.W.; Shui, W.J. Decomposition of Organic Matter by Soil Microorganisms in Terrestrial Carbon Cycling and Its Influence Factors. Chin. J. Soil Sci. 2005, 36, 605-609.

37. Chapman, S.J.; Campbell, C.D.; Puri, G. Native woodland expansion: Soil chemical and microbiological indicators of change. Soil Biol. Biochem. 2003, 35, 753-764. [CrossRef]

38. Griffiths, B.S.; Laurent, P. Insights into the resistance and resilience of the soil microbial community. Fems Microbiol. Rev. 2013, 37, 112-129. [CrossRef] [PubMed]

39. Kuntz, M.; Berner, A.; Gattinger, A.; Scholberg, J.M.; Mäder, P.; Pfiffner, L. Influence of reduced tillage on earthworm and microbial communities under organic arable farming. Pedobiologia 2013, 56, 251-260. [CrossRef]

40. Hanson, P.J.; Edwards, N.T.; Garten, C.T.; Andrews, J.A. Separating root and soil microbial contributions to soil respiration: A review of methods and observations. Biogeochemistry 2000, 48, 115-146. [CrossRef]

41. Wang, X.-X.; Yin, J.-J.; Xu, S.-Q.; Shen, L.-C. The variations of soil $\mathrm{CO}_{2}$ and hydrochemistry of Epikarst spring above Xueyue cave. J. Soil Water Conserv. 2013, 27, 85-89.

42. Cao, M.; Zhou, Z.; Zhang, J.; Yin, C.; Zhang, S. Effects of partial pressure of $\mathrm{CO}_{2}$ of water/gas on hydro-chemical process of cave water: A case study in Dolomite Cave System of Shuanghe Cave in Guizhou province. Environ. Sci. Technol. 2017, 40, 54-60.

43. Li, Y.; Zhang, K.; Wang, X. Assessment of the impact on shallow groundwater system by leakage of $\mathrm{CO}_{2}$ geological storage. Geotech. Investig. Surv. 2014, 42, 44-50.

(C) 2019 by the authors. Licensee MDPI, Basel, Switzerland. This article is an open access article distributed under the terms and conditions of the Creative Commons Attribution (CC BY) license (http://creativecommons.org/licenses/by/4.0/). 